\title{
A PARASZTI ÖNIGAZGATÁS KÖZÉPKORI EREDETE ÉS RÉTEGEI
}

\begin{abstract}
The peasant society had special autonomy from the Middle Ages. The local communities elected their own leaders, coordinated the common agricultural works of the land community, they judged on their own. Some characteristic attributes of these early autonomy survived the historical, political and social changes and remained dominant in the long run. In my study I present the genesis of the Hungarian villages and communities, the different components and layers of the traditional self-government. These questions are inseparable from the development of serfdom and its current situation. I point to the dichotomy inside of the communities, which stemmed from the property difference of the peasant society and from the conflicts of the individual and collective interests, which ones remained dominant till the end of 20 . century.
\end{abstract}

Magyarországon a falvak önigazgatásának sorsa már csak az elmúlt száz év alatt is több gyökeres átalakuláson ment keresztül. Nem csak a jogok, a lehetőségek, a kötelezettségek és a politikai rendszerek viszonylatában, hanem a helyi vezetőség társadalmi összetételének tekintetében is. A rendszerváltást követően a különböző tudományterületek más-más aspektusból értelmezik a változó társadalmi-politikai-gazdasági kereteket, melyek a középkelet-európai térségben elválaszthatatlanok a történeti parasztság sorsától.

A vidékkel foglalkozó társadalomtudományok szempontjából megkerülhetetlen a paraszti társadalom elmúlásának problémája, illetve az értelmezési keretek relevanciája. Kotics József a néprajztudomány oldaláról teszi fel a kérdést a rendszerváltás után újjáéledő paraszti mentalitással kapcsolatban: módszertanilag tartható-e az a megközelítés, amely a korábbi állapotok reliktumait keresi benne (Kotics 2011: 177)? Kijelenti, hogy a parasztság nem tért vissza Magyarországon a rendszerváltás után, annak ellenére, hogy a mai falusi társadalmak müködésében sok vonatkozásban találunk kapcsolódást a korábbi paraszti életformához. A parasztságról és annak polgárosodásáról kiterjedt és hosszadalmas diskurzus alakult ki a társadalomtudományokban, a néprajzban és a szociológiában. 2003-ban a Századvég hasábjain közölt polgárosodás vitában számos értelmezési szempontból, olykor ellentétes aspektusból ragadták meg a vitázó szerzők a 20-21. századi parasztság létezését, a szövetkezetiparasztságtól az utóparasztságon keresztül egészen a paraszttalanításig. A diskurzus tulajdonképpen a 2001-ben megjelent Europe's Green Ring c. kötetben használt paraszt fogalom hazai vitájaként robban be ${ }^{59}$. Kovách Imre 2012-ben megjelent „A vidék az

\footnotetext{
${ }^{59}$ Európa zöld gyürüjének, azaz későn iparosodó, agrárdominanciájú térségeinek (Kelet- és Közép-Európában, a skandináv, finn és mediterrán térségekben, Izlandon és Írországban) összehasonlító kutatásának eredményeként a mezőgazdaság modernizálása, az európai integráció, valamint a szocialista és posztszocialista korszakok hasonló eredményhez vezetek: az agrárnépesség nagyarányú csökkenéséhez és a történelmi parasztság eltűnéséhez (Kovách 2012: 175).
} 
ezredfordulón" c. kötetében önálló fejezetben foglalta össze a vita eredményeit (Kovách 2012: 174-202).

Az önigazgatással kapcsolatban Kovách Imre és Csite András kutatásai azt mutatják, hogy a volt gazdagparaszti réteg tagjai, annak leszármazottjai a rendszerváltás követő évtizedben felülreprezentáltak voltak a települési önkormányzatok képviselöi körében (CsiteKovách 2002). Ez összefüggésben állt a föld-kárpótlással és föld-visszaigényléssel, a „visszaparasztosodás” inkább csak remélt társadalmi folyamatával, illetve azzal a ténnyel, hogy vidéki önkormányzati választásokon jellemző módon a vezetők megválasztása sokkal inkább a helyi társadalomba való beágyazottságuktól függött, mint politikai álláspontjuktól vagy választási programjuktól (Csite - Kovách 2002: 240). (E tény a volt tanácselnökökre éppúgy érvényes, mint a tősgyökeres gazdagparasztság leszármazottjaira).

Az önkormányzatiságban felbukkanó régies elemek, lehetséges kontinuitások, történeti keretek közé helyezve válik érthetővé, hisz hosszú távú folyamatok eredményeként maradhattak meg a tradicionális népi önkormányzatok egyes elemi akár a 21. századig. Bizonyos szokásjogi elemei beépültek a modern polgári jogba, vagy a rendszerváltás hívta őket újra életre. Ilyen a parasztság vagyonos rétegének vezető szerepe, a presbitériumok társadalmi összetétel, a 19. században már egyesületi formákban müködő, de középkori eredetü közbirtokosságok intézményei, melyek jogi szabályozása tovább élt a szocializmus időszakában, sőt, tovább is60. A rendszerváltás után visszaigényelt erdők a legutóbbi időkig közbirtokosságokként müködtek, osztatlan közös tulajdonban maradtak, újjáéledtek a középkori gyökerü hegyközségek, Székelyföldön a közbirtokosságokkal együtt a székely tízesek rendszere (Tagányi 2015: 110).

Meglepően messze vezetnek a szálak, ha a fenti intézmények eredetét keressük. Nem elegendő a polgárosodó parasztság 18-19. századi történetéig visszanyúlni. A fennmaradt intézmények annál jóval régebben keletkeztek, jó részük a magyar jobbágyfalvak és önkormányzatuk kialakulásának időszakában. Jogfolytonosság szempontjából az önkormányzatok esetében is vízválasztóvá válik a rendi társadalom és jog „felszámolása”. Béli Gábor a jogtörténetben ezt a mérföldkövet 1861-re datálja. A községek jogállását végül 1871ben szabályozta részletes törvény, $\mathrm{s}$ választotta szét végérvényesen a korábbi rendi valóságban összeolvad gazdasági, bíráskodási és közigazgatási funkciókat, s teremtette meg a politikai értelemben vett községet. Márkus István is kiemeli, hogy feudalizmus felbomlásának viszonyai között a falusi önkormányzat új, politikai funkciókat kapott s épp ezért e korban különösen fontossá vált, mennyire épült ki, mennyire vált megszokottá, begyakorlottá az önkormányzás a korábbi századokban (Márkus 1988: 6).

Végső soron fel kell tennem a kérdést, honnan ered és mit is jelent a falvak önkormányzata? Mikor és miként keletkezett, honnan származik az a községi autonómia,

60 A téeszszervezésekig múködő legeltetési társaságok egyes szokásai - mi szerint a zselléreknek és a töredéktelkeseknek fübért kellet fizetnie a közös legelök használata után - bekerültek a tanácsi közigazgatásba és a szövetkezetek háztáji legeltetési bizottságok gyakorlatába is (Tagányi 2015: 109). 
amelynek elmúlásával, átalakulásával vagy túlélő maradványaival találkozunk? Ennek feltárásához a magam lehetőségeihez mérten ismertetem a magyarországi jobbágyfalu és a faluközösség önkormányzatának kialakulását. Jelen értelmezési keretbe nem tartoznak bele az önkormányzatok más formái, a nemesi községek vagy a kiváltságos kerületek (jászok, kunok, hajdúk) községeinek autonómiája, testületi önkormányzatok (a vizsgált időszakban még nem létező erdőközbirtokosságok és legeltetési társaságok, valamint a nyomásközösségek, a céhek és a hegyközségek) és az egyházi önkormányzatok (presbitérium) ismertetése.

\section{A tradicionális népi önkormányzat szervezete és feladatai}

Tekintettel arra, hogy a 11. században Magyarországon sem jobbágyság, mind rendi kategória, sem parasztság, sem jobbágyfalu nem létezett, ezért találó megfogalmazásnak tartom a Nagy Janka Teodóra által használ „tradicionális önkormányzat” elnevezést (Nagy 2000: 27). A kategóriát Béli Gábor tradicionális jogra vonatkozó definíciója alapján állította fel, aki a Szent István első dekrétumától a rendiség felszámolásáig, illetve az 1861-ig tartó jogtörténeti időszakot jelöli a kifejezéssel (Béli Gábor 1999: 19-20).

Márkus István megfogalmazásában, legáltalánosabb értelemben, „paraszti önkormányzat” alatt azt értjük, mikor „, a parasztság települési egységei - a falvak, községek„,maguk intézik ügyeiket”, vagy legalábbis erős beleszólásuk van azokba.” A paraszti létből fakadóan azonban ,a paraszti, falusi, községi autonómia mind gazdasági, mind politikai értelemben korlátozott" (Márkus 1988: 5). Márkus István felosztásában három, Szabó István rendszerezésében négy fö feladatkört láttak el az önkormányzat a falu életében (Tartalmilag tulajdonképpen azonosak, a két szerzőnél csoportosításuk tér el.). 1. Feladata volt mindenekelőtt a falu javainak gondozása és megtartása, ami a határok, határjelek, utak, vizek, árkok, hidak rendben tartását és gondozását jelentette. Ez a faluközösség tagjainak együttes érdeke volt. 2. Önigazgató tevékenységének legnagyobb teret a gazdasági élet szervezése engedett, a nyomásos müvelési rend állandó önkormányzó szervezetet kívánt meg. 3. Az előjáróság, a falusi bíró feladata volt a földesúr részére teljesítendő pénz és természetbeni szolgáltatások kivetése, beszedés és megszervezése (robot, fuvar, katonák elszállásolása, etc.)61 4. Végezetül bizonyos fokú falusi bíráskodást láttak el (faluszéke) a rend és béke fenntartása érdekében (Márkus 1988, Szabó 1969: 92-94).

A faluközösség, azaz a communitás legfőbb szerve a falugyülés volt, melyen a faluközösség minden tagja részt vett. Feladatiról a későbbi korok írásos emlékeiből lehet következtetni, melyek szerint a falu elöljáróinak a communitas gyülésén, a földesúr jelenlétében kellett elszámolni a közügyek kezelésével, e gyüléseken hirdették ki a faluszéke ítéletét, illetve olykor maga a falugyűlés is bíráskodhatott. A bíráskodás a falu önigazgatásának egyik leglényegesebb eleme volt. A falu széke, azaz a bíró és a 3-12 választott esküdt (hitesek, vének), vagy akár az egész faluközösség jelenlétében ítélkezett a rá bízott ügyekben. A bírónak a község általi választása vagy a földesúr által való kinevezése a parasztok és az urak közti

61 A faluközösség 13-14. századi igazságszolgáltatásáról és adóterheiről részletesen tájékoztat Bolla Ilona és Horváth Pál 1977-es „A középkori faluközösség, mint a feudális bíráskodás eszköze” c. tanulmányában. 
erőviszonyoktól függött, helyenként változó módon (Bolla 1977: 19). A szabad elöljáró választás a közszabad községek gyakorlatából került a feudális jobbágyfalvak körébe, illetve a hospes falvak esetében is elterjedt volt, mind a királyi, mind az egyházi, mind a világi birtokokon.

A földesúri fennhatóság alatt lévő jobbágyfalvak önigazgatásának egységes szabályozása a tradicionális jog időszakában nem történt meg. Hatáskörüket a jogszokás és a földesúrral való egyezség szabályozta, így az autonómia mértéke, a falu önkormányzata által végrehajtott feladatok igen különbözőek lehetetett. Az idővel lejegyzett szabálygyüjteményeknek két típusa különböztethető meg. A németül „Weisthumok”-nak nevezett falusi törvénykönyvek a parasztság kezdeményezéseit tartalmazták. Ilyen lejegyzett középkori székely falutörvényeket ismerünk Imreh István munkásságának köszönhetően. Szabó István Werbőczy István Hármaskönyvére utalva úgy vélte, hogy a jobbágyfalvak mindegyikének megvoltak a saját törvényei (Szabó 1969: 91). Az írásos szabálygyüjtemények másik, későbbi típusai a falurendtartások, azaz a „Hofordnung”-ok. Ezek a feudális birtokos által kiadott egyoldalú jognyilatkozatok a paraszti közösségek kötelezettségeit foglalták magukba (Szabó 1969: 90-91).

A falusi bírói tisztség, a falu vezetőjének latin villicus (vagy iudex, vagy maior villae) megjelölés már a 11. századi törvényeinkben megjelent. Ekkor a szabad községek vezetőjét értették alatta. A kifejezés 12. században eltünt, majd a 13. századi dokumentumokban vált újra gyakorivá, párhuzamosan a faluképződési, falutelepítési folyamatok kezdeteivel. Az átvett latin terminológia az antik rabszolgatartó mezőgazdaság hagyományaira utal, eredetileg egy-egy rabszolgatelep, kezdetleges település vezetőjének, majd az e hagyományokon kialakult európai feudális falurendszerben a falu vezetőjének megnevezésére szolgált (Szabó 1969, Tagányi 2015).

A várispánságok területén a 13. századi felbomlásukig a katonai százados és tizedes beosztás (decurionatus, decurionatus) vezetöi, a decuriok és centuriok voltak. A később ide is átterjedő villicus intézmény magyar megfelelőjében azonban tovább is megtartotta a katonai örnagy titulust. Míg a királyi várispánságok idővel az ország villicus rendszerhez alkalmazkodtak, egyes telepített falvak esetében nem csak nevüket, de szerepüket is megtartották a korábbi előjárók. Ilyenek voltak a rutén és román vidékek a vajdái és kenézei, valamint az észak-nyugati hegyvidék soltészi jog szerint telepített falvainak vezetöi, a soltészek (scultetus) (Szabó 1969: 96). E telepített falvak jogállása sokszor kedvezőbb, autonómiájuk kiterjedtebb volt a jobbágyfalvakénál.

\section{A faluközösségek és azok önkormányzatának eredete}

A faluközösségek és azok önkormányzatának eredete sokáig két szemlélet és ezzel két irányzat kereszttüzében állt. Az egyik szerint a földközösség és a faluközösség egy korai ősközösségi forma, mely megelőzte a magántulajdon kialakulását (őskommunisztikus elméletek). A másik értelmezési keretben az önkormányzattal ellátott, földközösségként müködő faluközösség 
feudális fejlemény, földesúri beavatkozás eredménye (földesúri vagy állami fiskális nézetek)62. Tagányi Zoltán véleménye szerint e kettőségnek a tudományos paradigmaváltáson túl fő oka, hogy a faluközösség genezisének két történeti rétege van: egy paraszti szokásjogon alapuló, a nemzetségi társadalom intézményeiből származó, közösségi akaraton alapuló rétege illetve egy ezzel szemben álló földesúri akarat, mely a gazdálkodó népességet telekrendszerbe és a földesúri adóztatás kötelékébe igyekezett belekényszeríteni (Tagányi 2015: 113). E komplex rendszert kísérlem megragadható részekre bontva bemutatni, az adózó jobbágyság, a falu és telekrendszer, valamint a nyomásközösségek kialakulásán keresztül.

\section{A jogilag egységes jobbágyság kialakulása}

A 10-13. század különböző jogállású, sokszor átmeneti állapotú társadalmi csoportjainak státuszát a jogképesség oldaláról lehet megközelíteni. Béli Gábor megfogalmazásában a régi magyar jogban általában minden ember jogképes volt, azaz jogok és kötelezettségek alanya lehetett, de a jogképesség terjedelmét meghatározta az egyén szabad (liber) vagy szolga (servus) állapota, később rendi állása, illetve neme (Béli 2014: 9). Ezen túl vagyoni helyzetük és függőségi állapotuk alapján alkottak csoportokat. A szabadok egységes szabadsága hamar differenciálódni kezdett, s közöttük a 9. század végétől már eltérő helyzetü, szabadságú és jogképességű csoportok rajzolódtak ki. A nemzetségi társadalom bomlásával, a birtokközösségek osztódásával a magas státuszú és vagyonú előkelők mellett kialakult az ugyan teljes jogképességgel, esetleg saját földtulajdonnal rendelkező, vagy azzal már nem is bíró közszabadok réteg. A 11. századtól kialakuló hatalmas kiterjedésü királyi birtokok és az egyházi birtokok, illetve a királyi várszervezet szabadjainak jogképessége ezzel szemben már korlátozott volt, szabadságuk területi keretek között érvényesült. Nem hagyhattak fel uruk szolgálatával s nem kötelezhették el magukat másnál (Bolla 1983, Béli 2014, Zsoldos 1999).

A világi birtokok szolgáló népei három kategóriába sorolhatók jogállásuk, termelőeszközökkel való ellátottságuk, illetve szolgáltatásaik minősége szerint: a szolgák (servus), a fél-szabadok (libertinus) és a szabadok (liberek) csoportjába (Bolla 1983)63. A világi házigazdaság munkaerőigényét elsősorban a servus-ok elégítették ki. Nem bírtak önálló gazdasággal és termelőeszközökkel, megtermelt javaikkal, családjukkal a földesúr korlátlanul rendelkezett, fenntartásuk és ellátásuk is az ő feladata volt. Ha a servus szerencsés esetben igavonó vagy fogatos állatra tudott szert tenni, s ezzel a földesúri üzem mellett saját kis gazdaságot létrehozni, lehetősége nyílt a földesúrhoz való szoros kötelék lazulására, a felemelkedésre. A királyi birtokok jelentős része magánkézbe került adománybirtok lett, melyet nem korlátoztak a nemzetségi eredetü kollektív tulajdon kötelékei, s ezzel rabszolgákkal

\footnotetext{
62 Tagányi Zoltán 2015-ben megjelent „A közép-kelet-európai faluközösség genezise” címmel kiadott összefoglaló tanulmánykötetében részletesen ismerteti a faluközösség és földközösség törtnetére vonatkozó kutatásokat és történeti munkákat. Nemzetközi kitekintése igen alapos, nyugat-európai, lengyel, orosz és magyar példákon keresztül mutatja be az Európában zajló faluképződési és falutelepítései folyamatokat, összevetve egymással a polgári és marxista történetírás hagyományait, eredményeit.

${ }^{63}$ Mint más esetben, úgy a szolgák állapotában sem jelentett azonosságot a latin servus kifejezés a római rabszolgák társadalmi helyzetével, jogképességével, illetve jogfosztottságával (Lásd részletesen Béli Gábor 2014 és Kelemen László 1927).
} 
müveltetett magánbirtok a 13. század végén robbanásszerüen háttérbe szorult64. Az individuális birtoklás előretörésével és az osztálytételekkel egyre nagyobb igény jelentkezett a vagyontárgyi jelleget nélkülöző termelőerő iránt. A servus-ok ugyanis a kollektív tulajdon részét alkották, felszabadításuk esetén a teljes családnak jelen kellett lennie.

A libertinus-ok már sokkal erősebben kötődtek magához a földhöz, s azon keresztül kapcsolódtak annak urához. Amennyivel a 13. században a servus-ok száma (jelentősen) csökkent, a libertinus-ok, azaz fél-szabadok száma ugyanennyivel nőtt. A korábbi felosztás alapját képező három tényező (termelőeszközökkel való ellátottság, jogképesség, szolgáltatások) szerint a libertinus-ok gazdaságilag a liberek-hez, jogi státuszukat tekintve a servus-okhoz álltak közelebb. Gazdasági helyzetük a szolga népeknél jóval előnyösebb volt, már meghatározott szolgáltatásokkal tatoztak a felettük hatalmat gyakorló földesúrnak, de nem költözhettek szabadon. Jellegzetesen a világi birtok szolgálói voltak, s jelentő s szerepet játszottak a jobbágyság kialakulásában. Bolla Ilona véleménye szerint oroszlánrészük volt a házigazdaságok korszerü feudális üzemmé alakításában, különösképpen, hogy sok servus a libertinus státuszon keresztül szabadult ki a rabszolgaságból és lett feudális paraszttá (Bolla 1983: 169).

A 13. század második felében azonban már elegendő lesüllyedt, a birtokosztályok következtében saját földjét elvesztő közszabad és a királyi birtokok felbomlásával kötöttségüktől megszabadult királyi népek álltak rendelkezésre a munkaerőigény kielégítésére (Bolla 1983). A világi birtokok harmadik szolgáltató csoportja, a liber-ek, függésbe került közszabadok voltak, akik szabadságukat, szabad költözésüket megőrizték. Státuszuk jóval magasabb volt a másik két csoporténál, nem álltak tulajdonosi függésben, nem adhattákvehették őket. A használatba vett földet nem úri kényszerből, hanem saját terület híján jól felfogott érdekükből művelték. Saját lovukkal, fogatukkal szolgáltak, sokszor fegyveres szolgálatot is teljesítettek. A 12. században a liber-eket ,jövevény” mivoltuk miatt - hisz szabadon költözhettek - gyakran hospes-nek, a 13. században szolgálataik, igazgatási feladataik miatt jobagio-nak nevezték (Az utóbbi kifejezés a várjobbágyok elnevezéséből származik, majd a 14. században kialakuló egységes jobbágyság megnevezésévé vált.)65.

A földesúri birtokok, ezen belül is a nagybirtokok kereti között a három szolgáltató réteg összeolvadásából, a libertinus státuszon keresztül tömegesen felszabadított szolgákból, a kötöttségüktől megszabaduló volt királyi birtokok szabadjaiból és a betelepülő hospes-ekből a 14. században kialakult a szolgáltatásaiban és jogaiban egységes jobbágyság66.

\footnotetext{
${ }^{64}$ A nagy és kisbirtokos között jelentős különbséggel zajlottak le ezek a változások. Míg a rabszolgákkal folyatatott gazdálkodás a nagybirtokok többségén a 13. században erősen visszaszorult, a kisbirtokokon még bőven virágkorát élte (Bolla 1983: 135). Egyrészt a kisbirtokosok servus-ainak csekély száma miatt kevesebb lehetőség volt a specializációra, másrészt a földterület mérete miatt nem éltek volna meg az arról befolyó paraszti járadékból.

${ }^{65}$ A várjobbágyságról lásd részletesen Zsoldos Attila: A szent király szabadjai 1999.

${ }^{66}$ Az magyarországi egységes jobbágyság kialakulásáról általánosan elfogadott Acsády Ignác 19-20. század fordulóján kifejtett álláspontja, mely szerint a különböző rendű szolga népek és az úri függésbe került lesüllyedt közszabad csoportjainak ötvöződéséből alakult ki az egységes jobbágyság. „Az ötvöződés előfeltétele a
} 
A különböző rétegek jogállásai, jogai és kötelékei azért érdekesek, mert beleolvadtak a feudális faluközösség önigazgatásába. A világi birtokok jobbágyparasztságának helyzetét két eltérő örökség jellemezte. Egyrészt alapvető terheik meghatározására a robottól megszabadult libertinus-ok ajándékai szolgáltattak mintát, továbbá a korábban tulajdonosi (propriusi) függésben álló népek feletti úri hatalom alapján jött létre a jobbágyok felett a földesúr bírói hatalma, a majdani úriszék alapja. Másrészt a feudális korlátok közé szorult közszabadok egyes jogai átterjedtek az egységesülő jobbágyság más eredetű, kötöttebb jogállású tagjaira. Így az adó többé már nem a termelő személyét, hanem annak gazdaságát terhelte, illetve a jobbágyság bírt bizonyos rendelkezési jogokkal a hozzá kapcsolódó gazdaság felett (elidegeníthette, örökíthette). „A hajdani közszabad községek önállósága átterjed és tovább élt a földesúri fennhatóság alatt kibontakozó 14. századi falusi önkormányzat alakjában” (Bolla 1983: 195). A falusi bíró intézménye és a falu közössége általi választás minden bizonnyal a közszabadok köréből eredt (Mind a világi birtok szabad népi, mind a királyi és egyházi birtokok hospes-ei maguk közül választották vezetőjüket.). S ugyancsak a közszabadság hajdani maradványainak tekinthető a 14. században a nemesi jogokkal hasonlóságot mutató jobbágyokat is megillető leánynegyed (quarta), a mortuarium és a javak feletti szabad végrendelkezés joga (Bolla 1983: 279). Az egysége jogállás kiemelkedő eleme volt az immár egységesen kiterjedt szabad költözési jog.

\section{A faluképződési és telepítési folyamatok, a feudális adóztatás}

A történelemtudomány álláspontja szerint a honfoglalás utáni időszakban - bár korábban feltételezték nemzetségi nagycsaládok létezését - a gazdálkodás, legalábbis a földművelés alapegységét a kiscsalád, a kiscsaládi szomszédságon alapuló törpefalvak jelentették. Tagányi Zoltán tájékoztatása szerint ez nem magyar sajátosság, hanem általános európai jelenség volt. Nyugat-Európában a 6-9. századig, Közép-Európában a 13. századig domináltak a termelésben a kiscsaládok, egészen addig, míg az irtásos váltógazdasággal szemben ki nem alakult az örökszántórendszer, a tanyák és tanyabokrok helyett a rendezett határú, háromnyomásos faluközösségek.

A 13. századi magyarországi úri- vagy köznemesi rabszolgatartáson alapuló praediumos vagy curiális házigazdálkodás is kiscsaládi szomszédságon alapuló településképlet volt. „Az ilyen curiák, ill. praediumok az egy alapitó östöl származó települések voltak, és ennek bizonyitékai az olyan „patronimikus” alapitó őstöl származó helységnév-végződések mint a: háza, -laka, -telke, -földje, és -szállása” (Tagányi 2015: 65-66). Bolla Ilona a 11-12. századból a világi birtokok bonyolult birtoklási viszonyairól tudósít, a nemzetségi csoporttulajdon és a kiscsaládok külön tulajdonban álló gazdaságok (praedium, sessio, curia) egymás mellett éléséről. A kettősség a gazdálkodásban is megmutatkozott. Míg a rokonság egészének csoporttulajdona föként álltartásra, addig a kiscsaládi, rokoni tulajdonban lévő földek

szolgarendű népek gazdasági helyzetének emelkedése volt, következménye pedig a földesúri függésbe került, személyükben elvileg szabad parasztokéval azonos jogi helyzet kivívása. Ez a fontos körülmény a szabad költözési jog (1298), majd az általános földesúri teher, a kilenced (1351) törvénybe foglalásával és általánossá válásával fejeződött be" (Bolla 1983: 10). 
elsősorban földmüvelésre szolgáltak67 (Bolla 1983: 100). Maksay Ferenc szerint a 11. században kialakuló településszerkezet az európai aprófalvakkal teljesen egyértékü, térben zárt településképletek voltak, s a királyi birtokok határőr népeinek, majd később a várjobbágyok települései is megfeleltek ennek a néhány családból és szolga népekböl álló formának (Maksay 1971: 43).

Az európai feudális falu római eredetével Szabó István foglalkozik először a magyar szakirodalomban, az 1963-as Agrártörténeti Szemlében megjelent „A prédium” c. tanulmányában. A szerző ebben az írásában fejti ki elméletét, mely szerint a ,rejtélyes” magyar praedium és a magyar falu az antik római villa leszármazottja. Tagányi Zoltán „A közép-keleteurópai faluközösség genezise" c. munkájában e tanulmánytól inspirálva vezeti le a nyugateurópai középkori faluközösség eredetét, majd ismeretei e folyamatok kései magyarországi megjelenését68.

A honfoglaló magyarság meghatározott ökológiai zónát szállt meg, a nagyállattartó pásztorkodásra alkalmas, jórészt lakatlan erdős sztyeppvidéket „A Nagy-Alföld a KeletDunántúllal és a Kis-Alfölddel együtt ugyanúgy a vizekben nem szegény erdös-sztyeppék övezetébe tartozott, mint a Fekete-tengertöl északra esö tájkorábban magyarok lakta részei. E síkságot három oldalról (keletröl, északról és nyugatról) körülölelö dombvidék pedig, ritkásabb, irtásoktól tarkitott tölgyeseivel hasonlóképp nem sokban különbözött a tölük, ahogyan a hegyek felé vezető néhány folyóvölgy és az erdélyi medence közepén fekvö Mezöség sem” (Maksay 1971: 25). Az erdős hegyvidék királyi birtokban lévő, jórészt lakatlan határörvidék lett. Az államalapítást követően megkezdődött a néptelen területek benépesítése. A létrejöttek a várispánságok, a királyi és házi birtokok, püspökségek és szerzetesrendek alakultak. A 11-13. század között kétszeresére nőtt a lakosság lélekszáma, s idővel a kedvezőtlenebb földrajzi területek is benépesítése is megkezdődött. A nemzetségek saját birtokukba vett szállásterületeik határa felé nyomultak, a köztük lévő hézagok kitöltésére a központi hatalom telepített sok esetben nyugati hospes-eket. A 12. században a nyugati határszél és az erdélyi folyóvölgyek irányába történt elörenyomulás, a 13. századtól az erdős

\footnotetext{
${ }^{67}$ Bolla Ilona és Maksay Ferenc is azon az állásponton van, hogy a későbbi jobbágyfalvak tagjainak általános legelőhasználati joga az állattartás e nemzetségi gyökereihez kötődik, s ez a jogszokás marad a legelőhasználat gyakorlatában még a 19. századi közbirtokosság kereti között is. Hozzá kell tennem, hogy Magyarországon az úri és jobbágyi erdő és legelők elkülönítése az európai gyakorlathoz képest rendkívül késői, legkésőbb a jobbágyfelszabadítás korában ment végbe.

${ }^{68}$ Röviden összefoglalva a római polgárok megélhetését nyújtó vidéki gazdaságuk (villa rustica) művelését idővel rabszolgák helyett szabad, szerződéses függésben álló colonus-okkal kezdték müveltetni. A colonus, a föld bérlője kölcsönös függőségbe került a bérbeadóval, annak használatáért naturális járadékokkal, a termés meghatározott részével, munkával, később renta-val, pénzjáradékkal tartozott. A villagazdaságok körül idővel vicus-ok, azaz kezdetleges faluszerü települések keletkeztek. A magyar szóhasználatban is elterjedt villicus, vagy conduktor/magister, aki eredetileg a rabszolgatartó villagazdaságot vezette, immár a járadékfizető függő paraszti elemek, conulus-ok ügyeinek intézője lett. A 6-7. században kialakuló feudális rendszerekbe a római gyökereken kialakult villicatios rendszer épült be s vált a feudális szolgáltatások és adóztatás alapjává. A középkorban az ókori példákhoz hasonlóan a curia tulajdonosa földjét két részre osztotta. Egyik részén saját üzemet müködtetett (dominum vagy magyarosan praedium) másik felét részekre, telkekre osztva bérbe adta. A bérlő pedig szolgáltatásokkal, a 12. századtól pénzjáradékkal, illetve a dominum-on való munkával tartozott földjének használatáért.
} 
hegyvidék irányban. A Magyarországra is eljutó technikai vívmány, a nehézeke vagy ágyeke lehetővé tette az erdők és nádasok irtásának nehéz munkáját. Az irtások szükségessége a fölmüvelés térhódításával, a könnyen müvelhető földterületek megfogyatkozásával is összefüggött, valamint a Magyarországon is megjelenő városiasodással, a kialakuló iparos rétegek növekvő gabonaigényével.

A földesúri (és egyházi) adománybirtokok majorságait, praedium-ait eleinte rabszolgák művelték, majd felváltotta őket az előzőekben ismertetett adózó jobbágyréteg. A jobbágyokat immár telekre, sessio-ra ültették, évi szolgáltatásokra és csekély munkavégzésre kötelezték. A földesúrnak ugyanis az adóztatásból több és biztosabb jövedelme származott, mint a majorsági vagy curiális gazdálkodásból, a pénzadóból pedig fedezni tudta megélhetéséti és katonáskodási kötelességit. A praedium-ok jó részéből a curiális nemesek adózó falvakat alakítottak ki, s a feudális adóztatás a jövedelemszerzés érdekében a falutelepítések hajtómotorjává vált (Bolla, 1977, Tagányi 2015). A telekrendszerrel ellátott adózó jobbágyfalvak először a Kárpátmedence azon központi részén alakultak ki, melyet közvetlenül a honfoglaláskor szállt meg a magyarság. (Tagányi 2015: 67). A gazdálkodás, faluszervezés, a faluközösség és a hozzá tartozó önkormányzat a mintáját a nyugati hospes-ek szolgáltatták. A szükséges technikai újítások (háromnyomásos művelési rend, nehézeke) pedig a fejlettebb gazdálkodást folyatató szerzetesrendek és föúri majorságok közvetítésével kerültek a hazai gyakorlatba)69.

E római gyökerekre épülő középkori faluképződési, illetve falutelepítési folyamatot Tagányi Zoltán villicatio-nak nevezi. A rendezett határú, háromnyomásos falvak telepítése a római gall provinciákban jelent meg először, német közvetítéssel került Közép-Kelet-Európába, ahol a 11-13. századi falutelepítési mozgalmakban csúcsosodott ki. A folyamat első fázisai Magyarországon csak a 10-13. században jelentkeztek, amikor is Nyugat-Európában már lecsengőben voltak a lokációs folyamatok. A tudatos falutelepítések Magyarországon - és Közép-Kelet-Európában - többször felelevenedtek, s többek között e későbbi 18. századi telepítések jobban dokumentált és ismert folyamatai alapján rekonstruálhatók középkori folyamatok (Tagányi 2015: 111-113).

A 13-14. században a Kárpát-medence északi, észak-keleti erdős térségeinek betelepítése a központi sík vidékek 10. századi spontán betelepülésével ellentétben tehát tudatos lokációs folyamat volt, s elsősorban a nagybirtokos nemesség szorgalmazta. A falualapítások nyugati mintára, nyugati telepesekkel történt, a hospes-ek otthoni jogállásainak, kiváltságainak átvételével (,németes jogú falvak”), azaz az általánosnál jóval kedvezőbb adózási és önigazgatási feltételekkel (évekig tartó adómentesség, szabad elöljáró- és papválasztás, bíráskodás, etc.) (Tagányi 2015: 68-69). Magyarországon az így telepített falvak az általános villa elnevezéssel szemben scultetia megjelölésre hallgattak, élükön a scultetus, magyarul soltész állt. A soltészok Magyarországtól északra is ismert nagy tervszerüséggel dolgozó hivatásos telepítők voltak, elsősorban az északi országrész németek és szlovákok lakta erdős hegyes területein tevékenykedtek. Kvázi vállalkozók, akik véghez vitték a telepítési folyamatot,

${ }^{69}$ A művelési rendekről, az eketípusok jelentőségről, a földmüvelés ,tökéletesedéséről” Belényesy Márta tudósít részletesen az Ethnographia c. folyóiratban 1954-ben megjelent tanulmányában. 
az erdei hegyes területeken szabályos telekrendszerü falvakat hoztak létre (Tagányi 2015: 67, Maksay 1971). Más esetben is jellemző volt, hogy a földterület birtoklója a benépesítés céljából átadta a földet bérlet vagy zálogjog formájában. Tekintettel arra, hogy a telepítésekhez tőke kellett, fáradtságos munkát igényelt, de pénzgyarapodást csak évek múlva eredményezett, így a kockázatot igyekeztek átruházni (Maksay 1983: 61).

E tudatos telepítések mellett a magyarság által korán megszállt falvak határainak rendezése (komasszáció) is szükségszerüvé vált. A tanyás jellegü települések határában szabad parlagváltó gazdálkodás folyt, a települések határában a szántók, rétek, legelők egymással keveredve helyezkedtek el. A korábbi alacsony népsürüség és a földbőség megengedte, hogy mindenki maga foglaljon és müveljen területet, de a 12-13. században itt is megjelenik a határrendezés szüksége, a földmüvelés és az állattartás érdekeinek összehangolása céljából. Ezekben a falvakban is telekrendszert alakítottak ki s egyre elterjedtebbé vált az intenzívebb müvelés és a legeltetés igényeit is kielégítő a két- vagy háromnyomásos gazdálkodás. Szabó István megfogalmazása szerint a feudális telek a „... falu legfontosabb alkotóeleme. Belöle származott a mezögazdálkodást üzö falusi nép minden hasznának forrása. Nem csak a telekhez füzödö tartozékok, hanem a közösségi és politikai jogok nagy része is a telekhez füzödött. A sessio, a jobbágytelek lényege, hogy a korábbi - a libertinus-okra jellemzö - mansio-val, házhellyel ellentétben, hogy hozzá tartozékok, pertinencia-k járnak. Fö alkotórészei a belsö házas telek, a mezöbeli müvelt föld, rét, és a határbéli használati jogok (erdő használat, vízhasználat)" (Szabó 1969: 11).

\section{A földközösség és a nyomásos gazdálkodás}

A rendezett határú, utcás, soros falutelepülések és a telekrendszer kialakulásával együtt járt a müvelési és birtoklási rend megváltozása is. A 13-14. századi nagy gazdasági és társadalmi változások keretében a mind elterjedtebbé vált földközösségi forma, a nyomásos gazdálkodásnak, esetleg örökszántónak nevezett müvelési rend. A magyar föld- és faluközösséggel kapcsolatos hazai kutatásokat Tagányi Károly indította el 1894-es „A magyar földközösség története” című tanulmányával. Már akkor jelentős szemléletbeli különbségek alakultak ki a témában a később marxistának és polgárinak nevezett történetírási hagyományok között, mely hosszú évszázadokra meghatározta a földközösségről és a paraszti önigazgatás eredetéről való gondolkodást. Az őskommunisztikus szemléletek szerint a faluközösség és annak autonómiája, önigazgatása az ősi földközösségben gyökeredzik. A polgári történetírás azonban már a múlt századfordulón megkérdőjelezte a közösségi tulajdon és a fölközösségek elsődlegességét. A hazai agrártörténeti kutatások későbbi álláspontja szerint Tagányi Károly is tévesen azonosította az első foglalás jogát, a nomád parlagváltó rendszert a nyomásosújraosztásos faluközösséggel, s tévesen feltételezte annak kontinuitását 18-19.századig. Wellman Imre már 1933-ban a Grassalkovich uradalom 18-19. századi gazdálkodását elemezve arra a következtetésre jutott, hogy a földközösség folytonossága a török idők alatt megszakadt, s 18. században újjáéledő szabad foglalás és parlagoló váltógazdálkodással a faluközösség és földközösség kialakulása előtti gyakorlat elevenedett fel. Tagányi Zoltán a 18. századi jelenséget a faluképződési folyamatok revitalizációjaként fogja fel. A tudománytörténeti vitáról kimerítő tájékoztatást ad Tagányi Zoltán (Tagányi 2015: 72-82 és 111-113). 
Szabó István kritikája szerint a faluközösség önkormányzata nem a nemzetségi alapú földközösségben gyökerezik, hanem a feudális falusi földközösség szomszédsági közösségében. Az önigazgatás forrása pedig nem a birtoklási rend (földközösség), hanem a hozzátartozó határhasználati mód, a nyomáskényszer okán jött lére. Az újraosztásos földközösség szabályozott határhasználata a korábbi szabadsággal ellentétben ugyanis megkövetelte a közösségi szabályozást, a gazdasági jellegü önigazgatást, a faluközösség önkormányzatát. A nyilas osztás füvön osztás keretében a falu határát minőségek szerint dủlőkre osztották, s művelésre e darabok mindegyéből sorsolás útján részesült a jobbágy, $\mathrm{s}$ tulajdonképpen a faluközösség tagjaként a nemes is70. A müvelésre kiosztott parcellák alapvetően a telek arányában jártak, ugyanakkor több forrás vonatkozik arra, hogy a jobbágyoknak igaerejük arányában juttattak földet. A falu határában a nehéz ekével való szántás miatt kialakított hosszú és keskeny nadrágszíj parcellákra osztott, akár 30-40 tagban szétszórt területet csak összehangolva lehetett megmunkálni a nélkül, hogy egymásnak kárt okoztak volna.

A faluközösség akarata, a közösségi rend legfőképp a földek használatát szabályozta, kijelölte az egyes müvelési ágakat, az őszi és tavaszi vetés, illetve az ugaron való legeltetetés helyét. „Ez a közösségi akarat a kollektív rend a földesúri adóztatás és biráskodás bevezetésével párhuzamosan hozta létre a nyomáskényszert, a közösségileg szabályozott két vagy háromnyomásos rendszert. Ezzel azonban a falközösség kollektív közösségi jellege ki is merült, ugyanis csak az egyes müvelési ágak összehangolása jelentette ezen akarat érvényesülését" (Tagányi 2015: 91). A gazdálkodási eszközök kezdetleges volta, sokszor az igaerő hiánya előhívta a kölcsönös segítségnyújtás igényét (eke- és igatársulás, azaz cimboraság), de ezen túl elszigetelten dolgoztak.

\section{A faluközösség az egyéni és a kollektív érdekek ütközésében}

A rendezett határú falu és a telekrendszer kialakulásával az adóztatás alapja az ekével megmüvelt föld lett. A nyomásrend létrejöttével, a rendelkezésre álló területek szükülésével a föld faluközösségi használata eleinte csak a falu közelében található szántókra terjedt ki. A belső területek nyomáskényszerével ellentétben a távolabb eső földeken megmaradhatott a szabadfoglalásos parlagoló gazdálkodás. A külső terültetek tanyái ugyanakkor szabadulást jelentettek földesúri adóztatás és a faluközösségi kötöttségek alól, szabadabb, individuálisabb földhasználatot biztosítottak. Az egyéni és a kollektív földhasználat dualizmusa, ellentétes érdekei tehát már igen korán jelentkeznek a faluközösség zárt keretein belül (Tagányi 2015: 92).

A falu közel sem volt olyan közösségi, mint az gondolnánk róla, illetve a kezdetektől jelen volt benne az individuális és kollektív érdekek ütközése. Az újraosztásos faluközösségen belül eleinte megnyúlik a szántók újraosztásának periódusa, majd idővel fel is hagynak annak osztásával, állandósul a használat. A vagyonosodó rétegnek nem állt érdekében az újraosztás, a közös földhasználat. A magánjellegü földhasználattal együtt járt a közösségen belüli

\footnotetext{
${ }^{70}$ A nyilas osztás, a nyílhúzás a földek - egyéni jelzéssel ellátott - nyílvesszővel történő sorsolását jelentette.
} 
differenciálódás, hiszen a földek, a telkek osztódhattak vagy növekedhettek az öröklés végett. Ezt a differenciálódást a faluközösség korai bomlásának jeleként szokták értelmezni. (Tagányi Zoltán 2015: 93, Szabó 1969: 17). A gyors aprózódás következtében a 15-16. század fordulójára már a fél telek volt általános (Maksay 1958, Szabó 1969). A telekaprózódások következtében a csökkenő létszámú, de növekvő vagyonú gazdagparasztság mellett megjelent a töredékbirtokos, háromnegyed vagy negyed telkes jobbágyság, zsellérség és a mezőgazdasági bérmunkásság. A valamelyes földdel (negyedtől nyolcad jobbágytelek), házzal vagy még azzal sem bíró zsellérség, bár önálló jobbágyi szolgáltatásokra nem volt képes, mégis kötötték bizonyos feudális kötöttségek és ennek következtében jogok is a faluközösséghez. (erdö- és legelőhasználati jog). A paraszti differenciálódásból és vagyoni különbségekből fakadó érdekellentétek, az egyéni és kollektív érdekek ütközése, melyek a 18-19. századi elkülönítések és tagosítási hullámok során hatványozottan jelentkeztek, s majd a falu vezetésében a gazdag paraszti réteg dominanciájához vezettek, már ebben a korai időszakban jelentkeztek a faluközösség életében.

\section{Zárszó}

A különböző rétegek egymásra rakódásával kialakult tradicionális népi önkormányzat, a paraszti önigazgatás kialakulásának kezdetén viszonylag kiterjedt volt. Szabó István szerint 1514-ig meglehetős autonómiával rendelkeztek a faluközösségek. Kevéssé volt jellemző a földesúri beavatkozás gazdálkodásba vagy a közéletébe, inkább a belső ellentmondások, érdekek ütközése hatott bomlasztóan a közösségre. A 16. századtól kibontakozó allodiális gazdálkodás, a jobbágyi terhek növekedésével, a szabad költözés megváltozása, az ország három részre szakadása a települések autonómiájában, a bírói tisztség megítélésében is változásokat eredményezett. A bíró folklórból is jól ismert negatív paraszti ábrázolása már a későbbi korok társadalmi és gazdasági valóságának leképződése. A faluközösségek önigazgatásának azonban olyan sajátságai jöttek létre kialakulásuk idején, melyek a 20-21. századi tulajdonszerkezetben, önkormányzatiságban is elöbukkannak. Reményeim szerint sikerült érzékeltetnem, hogy az egymásra rakódó történeti rétegek, a társadalmi és gazdasági jelenségek egymásra hatása minként alakított ki olyan intézményeket, melyek aztán szívósan képesek voltak fennmaradni.

\section{Irodalom}

Belényesy Márta (1954): A földművelés fejlődésének alapvető kérdései a 14. században. Ethnographia 65: 401-429.

Béli Gábor (2014): Magyar jogtörténet. A tradicionális jog. Pécs: Dialóg Campus Kiadó.

Bolla Ilona - Horváth Pál (1977): A középkori faluközösség, mint a feudális bíráskodás eszköze. In Bolla Ilona - Csizmadia Andor - Degré Alajos - Horváth Pál (szerk.): Tanulmányok a falusi közösségekről. Pécs: Pécsi tudományegyetem, 5-33.

Bolla Ilona (1983): A jogilag egységes jobbágyosztály kialakulása Magyarországon. Budapest: Akadémiai Kiadó. 
Csite András - Kovách Imre (2002): Vidéki történet. In Kovách Imre (szerk.): Hatalom és társadalmi változás. A posztszocializmus vége. Budapest: Napvilág kiadó, 212-295.

Csizmadia Andor - Kovács Kálmán - Asztalos László (1975): Magyar állam és jogtörténet. Budapest: Tankönyvkiadó.

Engel Pál (2003): Birtokosztály és családképződés. In Engel Pál (szerk.): Honor, vár, ispánság. Válogatott tanulmányok. Budapest: Osiris Kiadó, 625-637.

Kelemen László (1927): A jogképesség és a személyi állapot hazánkban az Árpád házi királyok alatt. Jogtörténeti Értekezések, 1. füzet. Szeged: Nemzeti Sajtóvállalat.

Kotics József (2011): Újjáéledő paraszti mentalitás? A reprivatizáció hatása a gazdálkodói stratégiákra és habitusokra. In: Vargyas Gábor (szerk.): Párbeszéd a hagyománnyal. A néprajzi kutatás múltja és jelene. Budapest: L’Harmattan Kiadó, 67-181.

Kovách Imre (2003): A magyar társadalom "paraszttalanítása" - európai összehasonlításban. Századvég, 2(28): 41-67.

Kovách Imre (2012): A vidék az ezredfordulón. A jelenkori magyar vidéki társadalom szerkezeti és hatalmi változásai. Budapest: Argumentum Kiadó.

Maksay Ferenc (1958): Parasztság és majorgazdálkodás a 16. századi Magyarországon. Budapest: Akadémiai Kiadó.

Maksay Ferenc (1971): A magyar falu középkori településrendje. Budapest: Akadémiai Kiadó.

Márkus István (1988): Paraszti önkormányzat a magyar rendi társadalomban és a kapitalizmus kiépülése idején. In Köles Sándor - Varga Csaba (szerk.): A helyi cselekvés. AJK Füzetek 38. Magvető Könyvkiadó.

Nagy Janka Teodóra (2000): A tradicionális népi önkormányzatok jogtörténeti vizsgálata a Dél-Dunántúlon - különös tekintettel a föld- és faluközösségek felbomlásának idöszakára. $\mathrm{PhD}$ értekezés.

Szabó István (1963): A prédium. Vizsgálódások a korai magyar gazdaság- és településtörténelem körében. Agrártörténeti Szemle, 3: 7-55.

Szabó István (1969): A középkori magyar falu. Budapest: Akadémiai Kiadó.

Tagányi Károly (1894): A földközösség története Magyarországon. Athenaeum Könyvkiadó.

Tagányi Zoltán (2015): A közép-kelet európai faluközösség genezise. Budapest: L’Harmattan Kiadó.

Wellman Imre (1989): Földközösségtől faluközösségig. Kutatások és felfogások Tagányi Károlytól Imreh Istvánig. Ethnographia, 100: 278-302.

Zsoldos Attila (1999): A szent király szabadjai. Fejezetek a várjobbágyság történetéböl. Budapest: MTA Történettudományi Intézet. 